\title{
One-Hundredth Annual Report of The American Phytopathological Society
}

\section{REPORT OF THE TREASURER}

The Financial Advisory Committee (FAC) and APS headquarters' staff met on 24 July 2008 in Minneapolis, Minnesota to celebrate our centennial, review financial matters related to the operation of the Society, and refine the APS strategic financial plan. FAC, headquarters staff, and leaders of APS business centers update and revise the strategic financial plan annually to make sure that funds are available to support all activities of the Society. An overall Society programmatic strategic plan is in place to put forth a strategy to meet the mission and vision for the future. Council and the officers regularly analyze the external environment and make progress toward assigning responsibility for developing and executing strategies to attain the goals of the Society strategic plan. Having a strategic financial plan helps us, as a Society, provide a focus for our resources and is used as a guide for the various committees and staff to do their jobs.
Strategic targets inform everyone as to what is expected from their programs several years in advance so they can build and execute strategies over several budget years. The role of FAC in this process is not to get involved in strategy building, but rather to develop financial goals, build business plans to meet those goals, and monitor progress towards each goal. FAC continually ask the difficult questions such as which programs should break even and which are expected to generate surplus to invest in our programs and services that best benefit our members? This plan continues to work for the Society allowing us to invest in our future.

The FY08 budget was concluded with a surplus of $\$ 21,764$, which represents $1 \%$ of our total income for the period. The 11 income and expense categories for the Society are detailed in Table 1. Our total income $(\$ 4,734,346)$ was derived from seven sources as indicated in Figure 1, and our total operating expenses $(\$ 4,712,582)$ incurred during FY08 were partitioned as indicated in Figure 2.

TABLE 1. Before audit summary of income and expenses as related to function of The American Phytopathological Society

\begin{tabular}{|c|c|c|c|c|c|c|c|c|c|}
\hline \multirow[b]{2}{*}{ Function } & \multicolumn{4}{|c|}{ Income } & \multicolumn{4}{|c|}{ Expenses } & \multirow[b]{2}{*}{ Profit (loss) } \\
\hline & Revenue & $\%$ & Budget & $\%$ & Expense & $\%$ & Budget & $\%$ & \\
\hline Member Services & 327,991 & $7 \%$ & 319,100 & $7 \%$ & 718,620 & $15 \%$ & 758,344 & $17 \%$ & $(390,629)$ \\
\hline Short Courses & 111,032 & $2 \%$ & 90,000 & $2 \%$ & 74,755 & $2 \%$ & 83,055 & $2 \%$ & 36,277 \\
\hline Phytopathology & 914,971 & $19 \%$ & 826,569 & $19 \%$ & 353,119 & $7 \%$ & 345,784 & $8 \%$ & 561,852 \\
\hline Plant Disease & 845,345 & $18 \%$ & 751,099 & $17 \%$ & 375,689 & $8 \%$ & 378,934 & $9 \%$ & 469,656 \\
\hline Phyto News & 13,580 & $0 \%$ & 8,265 & $0 \%$ & 45,791 & $1 \%$ & 53,600 & $1 \%$ & $(32,211)$ \\
\hline MPMI & 685,881 & $14 \%$ & 570,981 & $13 \%$ & 351,723 & $7 \%$ & 336,463 & $8 \%$ & 334,158 \\
\hline Plant Mgmt Network & 266,215 & $6 \%$ & 268,400 & $6 \%$ & 271,860 & $6 \%$ & 295,254 & $7 \%$ & $(5,645)$ \\
\hline Online Subs & 36,841 & $1 \%$ & 42,200 & $1 \%$ & 18,870 & $0 \%$ & 27,196 & $1 \%$ & 17,971 \\
\hline APS Press & $1,034,591$ & $22 \%$ & 840,939 & $19 \%$ & 777,760 & $17 \%$ & 695,415 & $16 \%$ & 256,831 \\
\hline Annual Meeting & 713,890 & $15 \%$ & 665,800 & $15 \%$ & 581,737 & $12 \%$ & 573,680 & $13 \%$ & 132,153 \\
\hline $\mathrm{G} \& \mathrm{~A}^{\mathrm{a}}$ & $(215,991)$ & $-5 \%$ & 32,200 & $1 \%$ & $1,142,658$ & $24 \%$ & 833,450 & $19 \%$ & $(1,358,649)$ \\
\hline Total & $4,734,346$ & $100 \%$ & $4,415,553$ & $100 \%$ & $4,712,582$ & $100 \%$ & $4,381,175$ & $100 \%$ & 21,764 \\
\hline Surplus (Loss) & & & & & & & & & 21,764 \\
\hline
\end{tabular}

${ }^{\mathrm{a}} \mathrm{G} \& \mathrm{~A}$ is assigned to functions based on payroll dollars.

Income

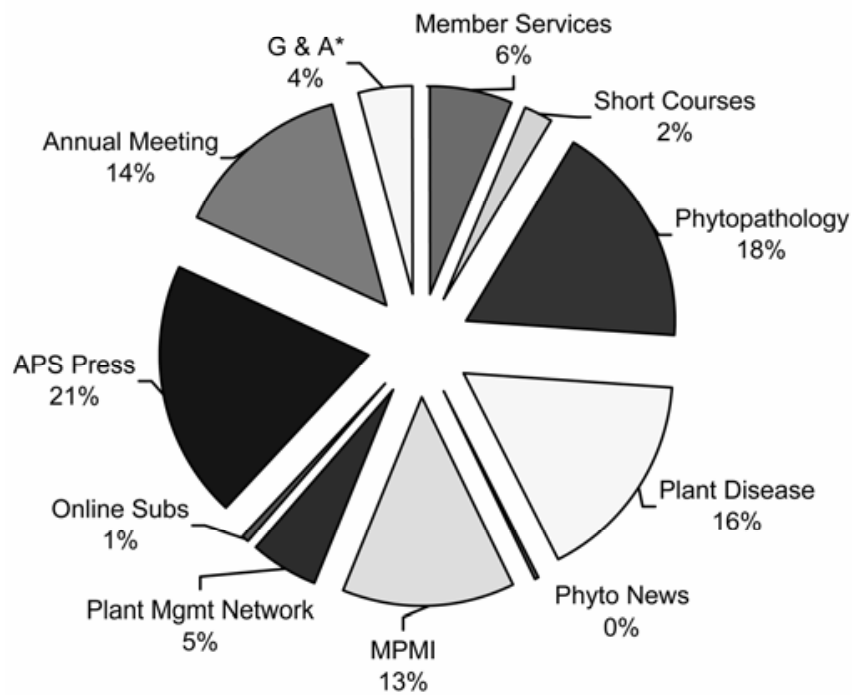

Fig. 1.

\section{Expenses}

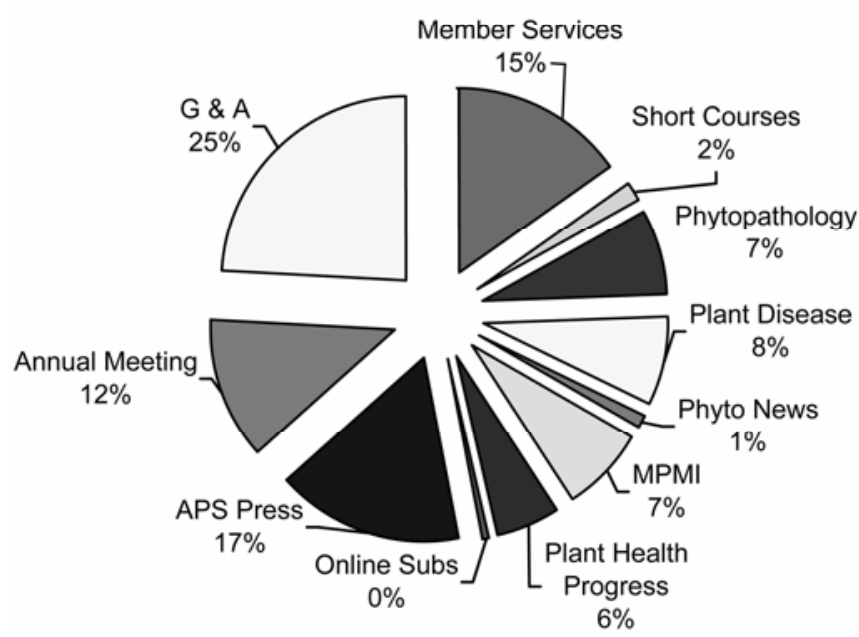

Fig. 2.

doi:10.1094/PHYTO-99-1-0017 
TABLE 2. Comparison of The American Phytopathological Society fiscal years 1994 to 2008 before reserve allocation

\begin{tabular}{lccc}
\hline Fiscal year & Income & Expenses & Surplus (deficit) \\
\hline FY08 & $\$ 4,734,346$ & $\$ 4,712,582$ & $\$ 21,764$ \\
FY07 & $\$ 4,538,077$ & $\$ 4,327,412$ & $\$ 210,665$ \\
FY06 & $\$ 4,289,254$ & $\$ 3,754,227$ & $\$ 535,027$ \\
FY05 & $\$ 3,959,027$ & $\$ 3,819,096$ & $\$ 139,931$ \\
FY04 & $\$ 3,963,006$ & $\$ 3,700,013$ & $\$ 262,993$ \\
FY03 & $\$ 3,748,845$ & $\$ 3,864,217$ & $(\$ 115,372)$ \\
FY02 & $\$ 4,045,587$ & $\$ 3,997,846$ & $\$ 47,741$ \\
FY01 & $\$ 3,952,594$ & $\$ 4,059,101$ & $(\$ 106,507)$ \\
FY00 & $\$ 3,649,863$ & $\$ 3,724,910$ & $(\$ 75,047)$ \\
FY99 & $\$ 3,662,093$ & $\$ 3,692,259$ & $\$ 30,166)$ \\
FY98 & $\$ 3,589,253$ & $\$ 3,431,727$ & $\$ 157,526$ \\
FY97 & $\$ 3,418,515$ & $\$ 3,216,088$ & $\$ 202,427$ \\
FY96 & $\$ 3,198,990$ & $\$ 2,974,105$ & $\$ 224,885$ \\
FY95 & $\$ 3,152,468$ & $\$ 2,907,285$ & $\$ 245,183$ \\
FY94 & $\$ 3,062,160$ & $\$ 2,902,793$ & $\$ 159,367$ \\
\hline
\end{tabular}

The income and expenses of the Society for the most recent 11 FYs are presented in Table 2. The total assets of the Society as of 30 June 2008, including restricted funds, were $\$ 8.0$ million and current liabilities totaled $\$ 2.6$ million. This resulted in total net assets of $\$ 5.4$ million.

The net income for the year was reduced by unrealized losses on investments of $\$ 209$ thousand or negative 5\%. However, program income continues to be positive and re-vested in the many Society initiatives that enhance member values including APS.net, our Washington, DC presence (Eversole Associates) and the increased use of reserves of the Society in supporting programming at the APS Annual Meeting, and investing in the Plant Management Network. The future of the Plant Management Network continues to look promising with increased content in four journals sponsored in part by over 60 partners while our presence in Washington continues to bring support to our discipline and Society. The Treasurer can be contacted at Rowe.4@OSU.edu. 